\title{
SYNTHESIS AND EVALUATION OF ANTI- INFLAMMATORY ACTIVITY OF SOME NEW PYRIDO [4, 3-D] PYRIMIDINE DERIVATIVES
}

Sarita Chaurasya ${ }^{1 *}$, S.Sharon Roja, T.Shreenilaya, M.Sangeetha, Y.Vinay Sree, M. Srivani.

Department of Pharmaceutical chemistry, Bojjam Narasimhulu Pharmacy College For Women, Vinaynagar, Saidabad. Hyderabad-500059.

Abstarct:In this investigation, we evaluated the anti-inflammatory activity of some new pyrido[4,3-d] pyrimidine analogous, by using animal model of carrageenan-induced paw edema in mice. New series of pyrido[4,3-d] pyrimidines derivatives were prepared in order to obtain new compounds with potential anti-inflammatory effect.A total of three novel pyrido pyrimidine derivatives compounds $(2.5 a, 2.5 b$ and $2.5 c)$ were synthesized by taking 4,6-diamino-2-bromo-3cyanopyridine as starting compounds and were characterized by different analytical technique like IR, NMR and Mass spectroscopy. The synthesized compounds were screened for their antiinflammatory potency in vivo by comparing with standard drug diclofenac sodium.It has been observed that the maximum anti-inflammatory activity wasrecorded by the compound 2.5ahaving $65.38 \%$ percentage protection of edema followed bycompound $2.5 b(60.25 \%), 2.5 c(50 \%)$ and Diclofenac sodium registered64.10\%. It has been found that the extent of increase in paw volume reducessignificantly up to 3 hrs when compared with solvent control.

Key words:Heterocyclic compound,Pyrido pyrimidine, Anti-inflammatory activity, Spectral analysis.

\section{I.INTRODUCTION}

Inflammatory reaction, typically characterized by redness, swelling, heat, and pain, is one of the most important host defense mechanisms against invading pathogens. However, persistent or over-inflammation leads to tissue damage and possibly the failure of organs.

The classical non-steroidal anti-inflammatory drugs (NSAIDs) are useful for the treatment of inflammation, pain and fever. The actions of NSAIDs are based on the inhibition of the enzyme cyclooxygenase (COX), which catalyzes the metabolism arachidonic acid (AA) to prostaglandin $\mathrm{H} 2$ (PGH2). PGH2 is further metabolized to prostanoids, prostaglandins (PGs) and thromboxane-A2 (TXA2). Various physiological effects of PGs include acute and chronic inflammatory reactions, blood pressure (BP) change, platelet aggregation, induction of labor and intensification of pain and fever. However, long-term usage of NSAIDs is associated with several side effects including gastrointestinal (GI) lesions, bleeding, as well as hepato- and nephro-toxicities ${ }^{2,3,4}$.

In designing new drug molecules, developing safer analgesic and anti-inflammatory drugs without such side effects has recently been the goal of many researchers. Different pharmacophores with a different mode of action in the structure may lead to compounds having efficiency in biological activity. Research has been directed in recent years, where a substantial number of pyrido[3,4-d]pyrimidine have been reported to possess various types of biological activities such as antimicrobial, antifeedant, herbicidal, antihypertensive, antipyretic, antiplatelet, anticancer, anticonvulsant, antitubercular, cardiotonic and other anticipated activities ${ }^{5,6}$. On the other hand, a considerable number of pyrido[3,4-d]pyrimidine derivatives are endowed with analgesic and antiinflammatory properties $^{7,8}$.

Diverse pharmacological activities of the compounds containing pyridazinone moieties ${ }^{9,10,11}$ have prompted us to synthesize new compounds with analgesic and anti-inflammatory activities that may be potent, selective and less toxic.

Stimulated by these findings, our attention has been focused on the synthesis and evaluation of some pyrido[4,3-d] pyridine derivatives $(2.5 \mathrm{a}-2.5 \mathrm{c})$ antiinflammatory agents using the carrageenan-induced oedema model. Indomethacin was used as reference drugs antiinflammatory activities.

\section{MATERIAL AND METHODS}

Experimental

Chemistry: All chemicals were obtained from commercial suppliers, and used without further purification. $1 \mathrm{H}$ and 
13C NMR spectra were recorded with a Varian Gemini 200 (1H NMR: $200 \mathrm{MHz}, 13 \mathrm{C}$ NMR: $50 \mathrm{MHz}$ ) or a Bruker Advance 300 (1H NMR: $300 \mathrm{MHz}, 13 \mathrm{C}$ NMR: $75 \mathrm{MHz}$ ), using tetramethylsilane as internal standard for 1H NMR spectra and DMSO-d6 (39.5 ppm) or $\mathrm{CDCl} 3(77.2 \mathrm{ppm})$ for 13C NMR spectra. Abbreviations used are: $\mathrm{s}=$ singlet, $\mathrm{d}=$ doublet, $\mathrm{t}=$ triplet, $\mathrm{q}=$ quartet, $\mathrm{m}=$ multiplet, br $\mathrm{s}=$ broad signal. Coupling constants are expressed in Hertz. Mass spectra are obtained with a Finnigan LCQ advantage Max (ion trap) mass spectrophotometer from Thermo Finnigan, San Jose, CA, USA. Exact mass measurements are performed on a quadrupole time-of-flight mass spectrometer (Q-tof-2,Micromass, Manchester, UK) equipped with a standard electrospray-ionization (ESI) interface.

Samples were infused in $i-\mathrm{PrOH} / \mathrm{H} 2 \mathrm{O}(1: 1)$ at $3 \mu \mathrm{l} / \mathrm{min}$. Melting points are determined on a Buchi SMP-20 apparatus and are uncorrected. Infra-red spectra were recorded on a Perkin ElmerSpectrum RX I FT-IR System in $\mathrm{KBr}$. Vibration frequencies in IR spectra are expressed in $\mathrm{cm}^{-1}$. Precoated aluminum sheets (Fluka Silica gel/TLCcards, $254 \mathrm{~nm}$ ) were used for TLC. Column chromatography was performed on ICN silica gel 63-200, $60 \AA$.

Synthesis of 4,6-Diamino-2-bromo-3-cyanopyridine (2.2)

$\mathrm{HBr}$ (in situ prepared from $\mathrm{H}_{2} \mathrm{SO}_{4}$ and $\mathrm{NaBr}$ ) was bubbled for 2 hours through a solution of malononitrile2.1 (13 $\mathrm{g}, 0.197 \mathrm{~mol})$ in toluene $(400 \mathrm{ml})$ at $0{ }^{\circ} \mathrm{C}$. A light yellow precipitate was formed and the reaction mixture was then heated at $100 \mathrm{oC}$ for 2 hours, with a lot of gas evolution. After cooling to room temperature, the yellow solid was filtered off and washed with toluene and air dried. The solid was mixedwith water and the $\mathrm{pH}$ of the suspension was adjusted to $9-10$ by the addition of a $33 \%$ aqueous NH3solution. After stirring at room temperature for 1 hour, the mixture was filtered. Recrystallization fromethanol afforded a yellow solid. After drying at $60 \mathrm{oC}$ in a vacuum oven, the title compound was obtained asan orange solid $(10.1 \mathrm{~g}, 48 \%)$.

\section{Synthesis of 3-Cyano-4, 6-diaminopyridine (2.3)}

To a solution of 4,6-diamino-2-bromo-3-cyanopyridine $\mathbf{2 . 2}(7 \mathrm{~g}, 32.8 \mathrm{mmol})$ in THF/MeOH $(2: 1,160 \mathrm{ml})$ was added potassium acetate $(4.54 \mathrm{~g}, 32.8 \mathrm{mmol})$ and $10 \% \mathrm{Pd} / \mathrm{C}(0.925 \mathrm{~g})$. The reaction mixture wasstirred under a hydrogen atmosphere (pressure of $1 \mathrm{~atm}$, using a balloon filled with hydrogen) at $25{ }^{\circ} \mathrm{C}$ for 4 hours. The mixture was filtered over Celite and the solvent was evaporated in vacuo. The solid wasdissolved in dilute $\mathrm{HCl}$ and water. Adjustment of the solution $\mathrm{pH}$ to 10 (with a concentrated NaOHsolution) and cooling afforded the title compound (3.94 g, $89 \%)$ as a yellow solid.

Synthesis 4, 6-Diaminonicotinamide (2.4)

A solution of 3-cyano-4,6-diaminopyridine $2.4(2.1 \mathrm{~g}, 15.7 \mathrm{mmol})$ in $90 \% \mathrm{H} 2 \mathrm{SO} 4(10 \mathrm{ml})$ was stirred at $60-70{ }^{\circ} \mathrm{C}$ for 3 hours. The resulting solution was poured into a $40 \% \mathrm{NaOH}$ solution to give a mixture of 4,6diaminonicotinamide as a pale yellow solid and inorganic salt $(2.1 \mathrm{~g}, 85 \%)$. An analytical pure samplewas obtained by recrystallization from water to give a pale yellow solid.

Synthesis of 7-Aminopyrido[4,3-d]pyrimidin-4(3H)-one (2.5a)

A solution of 4,6-diaminonicotinamide $2.5(2 \mathrm{~g}, 13.1 \mathrm{mmol})$ in triethylorthoformate $(60 \mathrm{ml})$ was refluxedunder a nitrogen atmosphere for 24 hours. The solvents were evaporated in vacuo and the residue wasredissolved in a hot $2 \mathrm{M} \mathrm{NaOH}$ solution $(20 \mathrm{ml})$ for 30 minutes and thereafter neutralized with a $6 \mathrm{~N} \mathrm{HCl}(6.5 \mathrm{ml})$ solution. On cooling, 7-aminopyrido[4,3-d]pyrimidin-4(3H)-one precipitated out. The yellow solidwas filtered off and was dried in a vacuum oven,

Synthesis of 7-Amino-2-methylpyrido[4,3-d]pyrimidin-4(3H)-one (2.5b)

A solution of 4,6-diaminonicotinamide $2.5(3 \mathrm{~g}, 13 \mathrm{mmol})$ in triethylorthoacetate $(60 \mathrm{ml})$ was refluxedunder $\mathrm{N} 2$ for 24 hours. After removing the solvent, the residue was dissolved in hot $2 \mathrm{M} \mathrm{NaOH}(20 \mathrm{ml})$ for 30 minutes and then neutralized with $6 \mathrm{~N} \mathrm{HCl}(6-7 \mathrm{ml})$. On cooling, 7-amino-2 methylpyrido[4,3-d]pyrimidin-4(3H)-one precipitates out. The yellow solid was filtered off and dried in a vacuum oven,affording the pure title compound $(2.4 \mathrm{~g}, 72 \%) . \mathrm{mp}>290{ }^{\circ} \mathrm{C}$.

Synthesis of 7-Amino-2-(methoxymethyl)pyrido[4,3-d]pyrimidin-4(3H)-one (2.5c)

To a solution of 4,6-diaminonicotinamide 2.5 (0.395 g, $2.6 \mathrm{mmol})$ in DMF (12 ml) was added methoxyacetyl chloride $(0.498 \mathrm{ml}, 5.45 \mathrm{mmol})$ and pyridine $(0.525 \mathrm{ml}, 6.46 \mathrm{mmol})$. The reaction wasstirred at room temperature under a nitrogen atmosphere for 3 hours. Then, $5 \mathrm{~N} \mathrm{NaOH}(8 \mathrm{ml})$ was addedand the reaction mixture was stirred for an additional 18 hours. The reaction mixture was concentrated invacuo and acidified with a concentrated $\mathrm{HCl}$ solution. On cooling, the product precipitates out. The paleyellow solid is collected by filtration and dried in a vacuum oven, furnishing the pure title compound $(0.27 \mathrm{~g}, 50 \%)$. mp $272-273{ }^{\circ} \mathrm{C}$. 


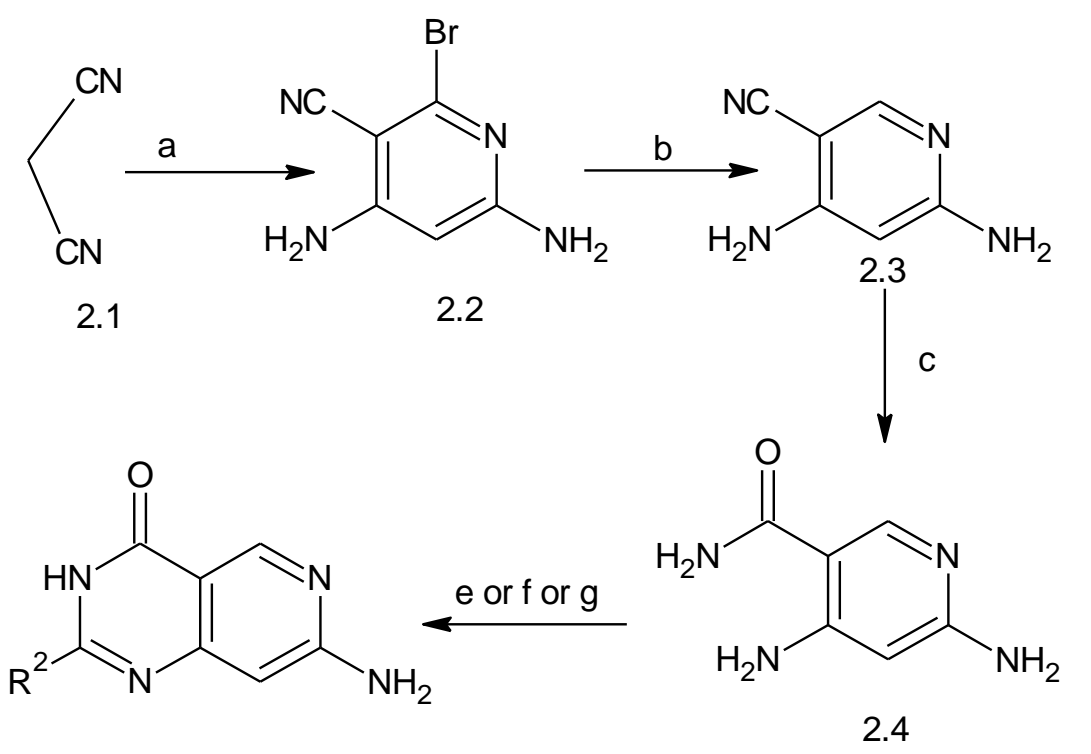

$2.5 a-c$

a) $\mathrm{HBr}(\mathrm{g}), 0{ }^{\circ} \mathrm{C}, 2 \mathrm{~h}$, toluene then $\left.\left.100{ }^{\circ} \mathrm{C}, 2 \mathrm{~h} ; \mathrm{b}\right) 10 \% \mathrm{Pd} / \mathrm{C}, \mathrm{H}_{2}, \mathrm{KOAc}, \mathrm{THF} / \mathrm{MeOH}(2: 1 \mathrm{v} / \mathrm{v}), \mathrm{rt}, 4 \mathrm{~h} ; \mathrm{c}\right)$ $90 \% \mathrm{H}_{2} \mathrm{SO}_{4}, 80{ }^{\circ} \mathrm{C}, 3 \mathrm{he}$ ) triethyl orthoformate, $140{ }^{\circ} \mathrm{C}, 24 \mathrm{~h} ; \mathrm{f}$ ) triethyl orthoacetate, $140{ }^{\circ} \mathrm{C}, 24 \mathrm{~h} ; \mathrm{g}$ ) methoxyacetyl chloride, pyridine, DMF, rt, $3 \mathrm{~h}$ then $5 \mathrm{~N} \mathrm{NaOH}$, rt, $24 \mathrm{~h}$

Scheme -1 Synthesis of pyrido[4,3-d] pyrimidine

Characterization and spectral analysis of synthesized compounds

7-Aminopyrido[4,3-d]pyrimidin-4(3H)-one (2.5a)

$\%$ of yield $(1.28 \mathrm{~g}) 60 \%$;

${ }^{1} \mathrm{H}$ NMR $\left(200 \mathrm{MHz}\right.$, DMSO- $\left.d 6,25{ }^{\circ} \mathrm{C}\right): \delta=11.80$ (br s, $\left.1 \mathrm{H}, \mathrm{NH}\right), 8.72(\mathrm{~s}, 1 \mathrm{H}, \mathrm{H}-5), 7.97$ (s, $\left.1 \mathrm{H}, \mathrm{H}-2\right), 6.75$ (br s, $2 \mathrm{H}, \mathrm{NH} 2), 6.36$ (s, $1 \mathrm{H}, \mathrm{H}-8) \mathrm{ppm} .{ }^{13} \mathrm{C}$ NMR (50 MHz, DMSO-d6, $25 \mathrm{oC}$ ): $\delta=163.83,160.31,154.90,150.23$, 149.17, 108.98, 98.93 ppm. MS: calcd for $\mathrm{C}_{7} \mathrm{H}_{7} \mathrm{~N}_{4} \mathrm{O}\left[\mathrm{M}^{+} \mathrm{H}\right]^{+}$163.16, found 163.31.

\section{7-Amino-2-methylpyrido[4,3-d]pyrimidin-4(3H)-one (2.5b)}

$\%$ of yield $(2.4 \mathrm{~g}, 72 \%)$. mp> $290 \mathrm{oC}$.

${ }^{1} \mathrm{H}$ NMR (200 MHz, DMSO-d6, $25 \mathrm{oC}$ ): $\delta=11.79$ (br s, $1 \mathrm{H}, \mathrm{NH}$ ), 8.68 (s, $\left.1 \mathrm{H}, 5-\mathrm{H}\right), 6.68$ (brs, $2 \mathrm{H}, \mathrm{NH} 2$ ), 6.28 (s, $1 \mathrm{H}, 8-\mathrm{H}), 2.25$ (s, $3 \mathrm{H}, 2-\mathrm{CH} 3$ ) ppm. ${ }^{13} \mathrm{C}$ NMR (50 MHz, DMSO-d6, 25 oC): $\delta=163.8,161.3,158.4,155.1$, 150.0, 107.4, 98.3, $21.6 \mathrm{ppm}$. MS: calcd for $\mathrm{C} 8 \mathrm{H} 9 \mathrm{~N} 4 \mathrm{O}\left[\mathrm{M}^{+} \mathrm{H}\right]^{+} 177.18$, found 177.30.

\section{7-Amino-2-(methoxymethyl)pyrido[4,3-d]pyrimidin-4(3H)-one $(2.5 \mathrm{c})$}

$\%$ of yield $\left(0.27 \mathrm{~g}, 50 \%, \mathrm{mp}>290{ }^{\circ} \mathrm{C}\right.$

$1 \mathrm{H}$ NMR (200 MHz, DMSO-d6, 25 oC): $\delta=11.70$ (br s, $1 \mathrm{H}, \mathrm{NH}), 8.71(\mathrm{~s}, 1 \mathrm{H}$,

5-H), 6.74 (s, $2 \mathrm{H}, \mathrm{NH} 2), 6.35$ (s, $1 \mathrm{H}, 8-\mathrm{H}), 4.24$ (s, $2 \mathrm{H}, 2-\mathrm{CH} 2), 3.33$ (s, $3 \mathrm{H}, \mathrm{OCH} 3) \mathrm{ppm}$. 13C NMR (50 MHz, DMSO- $d 6,25 \mathrm{oC}): \delta=164.0,161.2,157.9,154.7,150.4,108.0,99.0,71.6,58.7 \mathrm{ppm}$. IR (KBr): $v^{\sim}=3407,3328$, 3201, 2826, 1697, 1655, 1598, 1486, 1261, $1115 \mathrm{~cm}-1$. MS: calcd for C9H11N4O2 [M+H]+207.21, found 207.21.

\section{In vivo anti-inflammatory activity test}

The anti-inflammatory activity was assessed as suggested by Winter $e t a l^{12}$ by using carrageenan as edematogenic agent on adult albino rats of either sex weighing between 125-150g. The selected albino rats were housed in groups of six each in acrylic cages underlaboratory conditions. The test compounds were administered intraperitoneally in the form ofsuspension with tween-40 and normal saline at a dose of $50 \mathrm{mg} / \mathrm{kg}$ b.w. The Diclofenacsodium $10 \mathrm{mg} / \mathrm{kg}$ was used as reference standard and administered in a similar manner. Thecontrol group received the solvent (tween- $40+$ normal saline) at $2 \mathrm{ml} / \mathrm{kg}$ b.w. in a similarmanner. All the test samples were administered 30mins before injection of carrageenan $(0.1 \mathrm{ml}$ of $1 \% \mathrm{w} / \mathrm{v}$ in normal saline $)$ into the sub-plantar region of left hind paw of each rat.

The contra-lateral paw was injected with an equal volume of saline. The increase in pawswelling (volume) was determined by plethysmometer by calculating the difference betweenthe volumes of the mercury displaced by the two paws in $\mathrm{ml}$. The increase in paw volumewas measured at $1,2 \& 3 \mathrm{hrs}$ after the administration of the test compounds. The percentageprotection of edema was calculated at the end of $3 \mathrm{hrs}$ as per the following formula.

Percentage of protection $=\frac{\mathrm{Pc}-\mathrm{Pt}}{\mathrm{P} c} \times 100$ 
Where PC $=$ Increase in paw volume at time ' $\mathrm{t}$ ' of solvent control $\& \mathrm{Pt}=$ Increase in paw volume at time ' $\mathrm{t}$ ' of test.

Table 3: Anti-inflammatory activity of Pyrazole derivatives $(2.5 \mathrm{a}-\mathrm{c})$ In Rats byCarrageenan induced hind paw edema model

\begin{tabular}{|l|l|l|l|l|l|}
\hline \multirow{2}{*}{ Sl. No. } & \multirow{2}{*}{ Compd } & \multicolumn{3}{|l|}{ Increase in paw vol $(\mathbf{m l})$} & \multirow{2}{*}{ \% protection at 3h } \\
\cline { 3 - 6 } & & $\mathbf{1 h}$ & $\mathbf{2 h}$ & $\mathbf{3 h}$ & \\
\hline 1 & Solvent & $0.48 \pm 0.02$ & $0.73 \pm 0.03$ & $0.78 \pm 0.01$ & - \\
\hline 2 & Diclofenac & $0.38 \pm 0.02 * *$ & $0.33 \pm 0.04 * * *$ & $0.28 \pm 0.03 * * *$ & 64.10 \\
\hline 3 & $2.5 \mathrm{a}$ & $0.24 \pm 0.03 * * *$ & $0.29 \pm 0.01 * * *$ & $0.27 \pm 0.03 * * *$ & 65.38 \\
\hline 4 & $2.5 \mathrm{~b}$ & $0.36 \pm 0.03 * *$ & $0.49 \pm 0.06 * *$ & $0.47 \pm 0.02 * * *$ & 39.74 \\
\hline 5 & $2.5 \mathrm{c}$ & $0.27 \pm 0.03 * * *$ & $0.34 \pm 0.05 * * *$ & $0.31 \pm 0.05 * * *$ & 60.25 \\
\hline
\end{tabular}

Values expressed as Mean \pm SEM, $\mathrm{n}=6,{ }^{*} \mathrm{p}<0.05, * * \mathrm{p}<0.01, * * * \mathrm{p}<0.001$, Dose of the testcompound: $50 \mathrm{mg} / \mathrm{kg}$.

\section{Statistical analysis}

Results were expressed as means \pm s.e.m. Statistical significance was analyzed by using the one-way analysis of variance followed by Tukey's Multiple Comparison Test where $\mathrm{p}<0.05$ was accepted to be a significant difference.

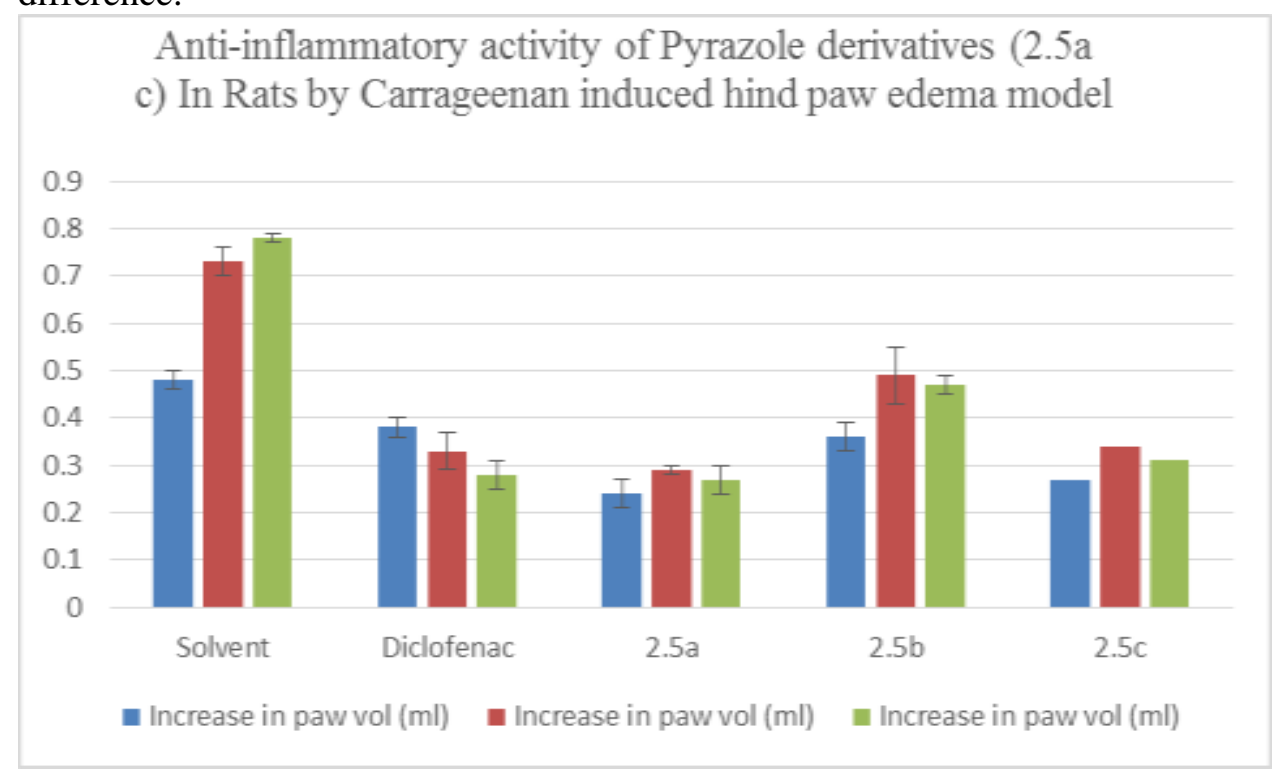

\section{RESULT AND DISCUSSION}

The anti-inflammatory activity of present synthesized compounds was evaluated bycarrageenan induced acute inflammatory method in rats on comparison with standarddiclofenac sodium. The result revealed that the all synthesized compounds shown anti-inflammatory activity $(* \mathrm{p}<0.05, * * \mathrm{p}<0.01$, *** $<<0.001)$ when compare to control andpositive control group. These showed the percentage protection of edema ranges between 39.74 and 65.38 at the end of $3 \mathrm{hrs;}$ where as the standard drug Diclofenac sodium registered64.10\% (Table -2 ). It has been observed that the maximum anti-inflammatory activity wasrecorded by the compound 2.5ahaving $65.38 \%$ percentage protection of edema followed bycompound $\mathbf{2 . 5 b}(60.25 \%)$, 2.5c(50\%). Thecompound 2.5a showed more percentage protection of edema than that of standard drugDiclofenac sodium. It has been found that the extent of increase in paw volume reducessignificantly up to $3 \mathrm{hrs}$ when compared with solvent control.

\section{Conclusion}

In conclusion, we reported here several pyridazinone compounds as analgesic and anti-inflammatory agents. Further investigations in the future should determine analgesic and anti-inflammatory potency for title compounds, the effect of specific substituents and their positions in the molecules, and their related toxicity.

\section{REFERENCES}

1. Janero, D.R. Malondialdehyde and thiobarbituric acid reactivity as diagnostic indices of lipid peroxidation and peroxidative tissue injury. Free Radic. Biol. Med. 1990, 9, 515-540.

2. HALLAS, J.; LAURITSEN, J.; VILLADSEN, H.D.; GRAM, L.F. Nonsteroidal anti-inflammatory drugs and upper 
gastrointestinal bleeding, identifying high-risk groups by excess risk estimates. Scand. J. Gastroenterol., v.30, p.438-444, 1995.

3. MCCARTHY D. Nonsteroidal antiinflammatory drug-related gastrointestinal toxicity: definition and epidemiology. Am. J. Med., v.105, n.5A, p.3S-9S, 1998.

4. RASKIN, J.B. Gastrointestinal effects of nonsteroidal antiinflammatory therapy. Am. J. Med., v.106, p.3S-12S, 1999.

5. JING, T.; DUO-ZHI, W.; LING-HUA, C. Synthesis of 5-(6-Pyridazinone-3-yl)-2-lycosylamino-1,3,4-oxadiazoles. J. Chinese Chem. Soc., v.54, p.1287-1292, 2007.

6. ISLAM, M.; SIDDIQUI, A.A.; RAJESH, R. Synthesis, antitubercular, antifungal and antibacterial activities of 6-Substituted Phenyl-2-(3'-Substituted Phenyl Pyridazin6'-yl)-2,3,4,5-Tetrahydropyridazin-3-one. Acta Poloniae Pharm., v.65, n.3, p.353-362, 2008.

7. SIDDIQUI, A.A.; KUSHNOOR, A.; WANI, S.M. Synthesis and hypotensive activity of some 6-(substituted aryl)-4- methyl-2,3dihydropyridazin-3-ones. Indian J. Chem-B, v.43B, p.1574-1579, 2004.

8. DOGRUER, D.S.; UNLU, S.; KUPELI, E.; BANOGLU, E.; SAHIN, M.F. Synthesis of 2-[5,6-diphenyl-3(2H)- pyridazinone-2yl] acetamide and 3-[5,6-diphenyl-3(2H)- pyridazinone-2-yl]propanamide derivatives as Analgesic and anti-inflammatory agents. Turk. J. Pharm. Sci., v.4, p.57-70, 2007.

9. DOGRUER, D.S.; SAHIN, M.F.; KÜPELI, E.; YEŞILADA, E. Synthesis and analgesic and anti-inflammatory activity of new pyridazinones. Turk. J. Chem., v.27, p.727-738, 2003.

10. SUKUROGLU, M.; KUPELI, E.; BANOGLU, E.; UNLU, S.; YESILADA, E.; ŞAHIN, M.F. Synthesis and analgesic activity of some 4,6-disubstituted-3(2H)-pyridazinone derivatives. Arzneim. -Forsch., v.56, p.337-345, 2006.

11. BAYTAS, S.; TURANDURAL, N.N.; OZKAN, Y.; SIMSEK, H.B.; GURSEL, T.; UNLU, S. Synthesis, anti-inflammatory, antiplatelet and in silico evaluations of (E)-3-(3-(2,3- dihydro-3-methyl-2-oxo-3H-benzoxazole-6-yl)-1-phenyl1H-pyrazole-4yl)acrylamides. Turk. J. Chem., v.36, p.367-382, 2012.

12. Winter CA, RislyEA ,Nuss CW, Proc. Exp. Biol. Med., 1962, 111 - 544. 